\title{
Rockburst of parameters causing mining disasters in Mines of Upper Silesian Coal Basin
}

\author{
Renata Patyńska ${ }^{1 *}$, Adam Mirek $^{2}$, Zbigniew Burtan ${ }^{3}$, Elżbieta Pilecka $^{4}$ \\ ${ }^{1}$ Central Mining Institute, 40-166 Katowice, pl. Gwarków 1, Poland; \\ ${ }^{2}$ State Mining Authority, 40-055 Katowice, ul. Poniatowskiego 31, Poland; \\ ${ }^{3}$ AGH University of Science and Technology, 30-059 Kraków, al. Mickiewicza 30, Poland, \\ ${ }^{4}$ Politechnika Krakowska, 31-155 Kraków, Warszawska 24, Poland
}

\begin{abstract}
In the years 2001-2015, 42 rockbursts were recorded in Polish coal mines. For the past 15 years the scale of the phenomena has been similar and ranges from 1 to 5 rockbursts per year. However, the number of recorded high energy seismic tremors of $10^{8}$ and $10^{9} \mathrm{~J}(\mathrm{E})$ energy that has occurred in recent years, 2 to 5 , is alarming. According to the data, 27 of tremors of $\mathrm{E}>10^{8} \mathrm{~J}$ energy that occurred between 2001 and 2015 caused 3 rockbursts. Confronting these data with seismic activity from 1989-2000, it should be noted that only 2 events out of 99 rockbursts caused tremors with energies of $\mathrm{E}>10^{8} \mathrm{~J}$. Against the background of the scale of seismic and rockburst hazards, the geological and mining conditions of the Upper Silesian Coal Basin (USCB) have been analysed, detailing the structural units in which the rockbursts occurred. On this basis, the author characterised factors that impacts on the mining excavations resulting in rockbursts that caused damage on a larger scale. These rockbursts had the characteristics of mining catastrophes and weak earthquakes not recorded in mining statistics of natural hazards of USCB so far.
\end{abstract}

\section{Introduction}

In the meaning of the applicable "Geological and Mining Law" [1] in Poland, "rockmass is a discharge of spring energy accumulated in the rock, manifesting rock mass and acoustic phenomena." A particular case of tremor is a rockburst. It is defined as: "a rapid discharge of elastic energy accumulated in rock mass, characterised by vibrations of rock mass carrying considerable energy, acoustic effects and a shockwave; this phenomenon causes destruction of rock structure in a roof, floor or bed with simultaneous dynamic rock relocation that fall into an excavation, and results in damages or destruction of the roof support or machinery and equipment."

\footnotetext{
* Corresponding author: rpatynska@gmail.com
} 
In the Upper Silesian coal mines, over a hundred years of rock tremors have been occured. High-energy tremors are also felt on the surface, and even cause damage to cubature and linear structures.

The seismic hazard and the risk of rockbursts in Poland is currently occurring in most coal mines. Statistics $[2,3]$ show that both the seismic and the rockburst risks increase year by year. It is conditioned by mining, geological, and technical and economic factors [4]. The most important of these are the natural factors, also referred to as geological. These include the initial rockmass pressure resulting from the deep mining $(>760 \mathrm{~m})$, rock properties and rock mass tectonics (faults). Other factors largely impacting on the risk of rockburst in the roof are so-called tremor-prone layers, especially with high strength and thickness $[5,6,7]$.

The next group are mining factors, which include, but are not limited to, the effects of exploitation (edges and residues) in neighbouring seams and limited operating conditions resulting from surface protection, residual deposit selection and "scarce" development work.

The aim of the analysis and research presented in the article was to indicate the mining and geological conditions characterising the areas where rockbursts have occurred in the last 15 years in the mines of the Upper Silesian Coal Basin (USCB).

\section{General characteristics of rockubrsts in USCB mines}

The rockburst hazard level in the USCB mines is illustrated by statistical data on the number of rockbursts recorded between 1949 and 2015 (Fig. 1) [2].

Between 1949 and 1962, 109 to 506 rockbursts yearly were recorded in the hard coal mining industry with output ranging from 78 to 104 million tonnes.

Since 1963, the number of rockbursts has dropped below 84 cases a year and continues to decline. Since 2009, production has been gradually decreasing, from 77.50 to 72.19 million tonnes in 2015. Data show that at output below 80 million tons, a comparable number of rockbursts, 1.57 every year.

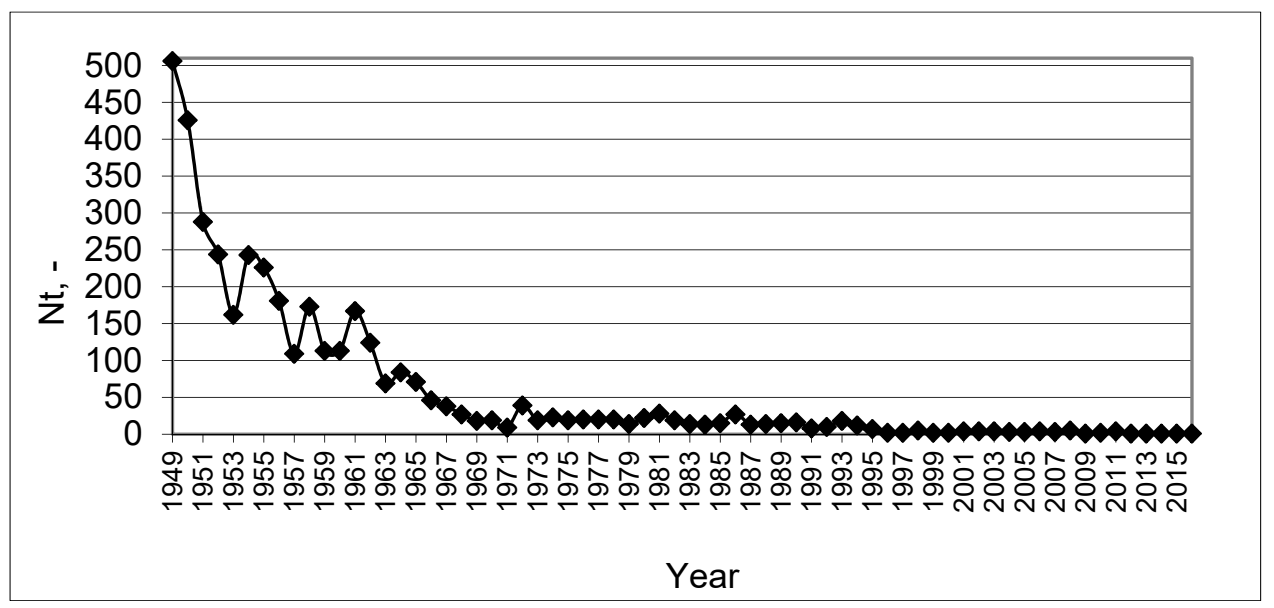

Fig. 1. Number of rock bursts (Nt, -) in USCB hard coal mines between 1949 and 2015 [2]

In spite of the more unfavourable mining and geological conditions in the vicinity of exploited seams, affected by past exploitation, the continuous development of mining technologies, mining experience and the use of effective prevention resulted in the 
occurrence of 1 to 5 rockbursts per year in the last 15 years (Fig. 2). It should be noted that only in 2008 the number of recorded seismic events amounted to 5.

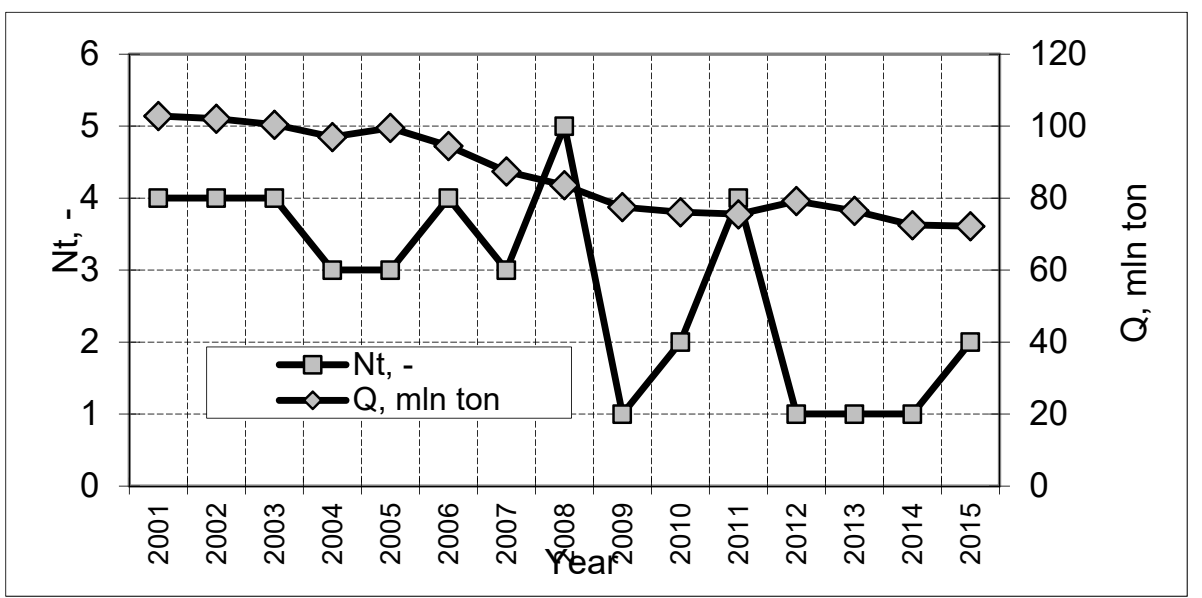

Fig. 2. Extraction of hard coal (Q, million tonnes) and number of rock bursts (Nt, -) in USCB mines in 2001-2015 [2]

The analysis of seismic activity distribution for individual USCB structural units indicates that the tremors are generated by mining operations and are located in five regions: Bytom Trough (NB), Main Saddle (SG), Main Trough (NG), Kazimierz Trough (NK), and Jejkowice and Chwałowice Troughs (NJ) [3].

It should be emphasized that between 2001 and 2015, the rockbursts were recorded only in three regions, namely Bytom Trough (NB), Main Saddle (SG) and Jejkowice and Chwałowice Troughs (NJ) [8]).

The characteristics of the regions indicate that seismic events that has led to rockbursts occur during the exploitation of deposits located at great depths, in the vicinity of fault zones, among the compact rocks. With the increase in the depth of the longwall operation and the preparatory work, there is a systematic deterioration of geological and mining conditions. In connection with the drawing process of coal resources, the mines more and more often decide to conduct exploitation of deposits in areas with residues, edges and/or in the area of former exploitation.

\section{General characteristics of USCB seismicity}

Between 2001 and 2015, the level of seismic activity was changing and depended on both the intensity of exploitation (total output) and the variability of the lithological and tectonic rock formations of the USCB.

Seismic activity was accompanied by the operation currently being conducted in five USCB regions (i.e.: $\mathrm{NB}, \mathrm{SG}, \mathrm{NG}, \mathrm{NK}$, and $\mathrm{NJ}$ ) and is very diverse, ranging from tremors not detected by humans to events with characteristic of small earthquakes $[9,10]$.

The most active seismic areas in the USCB are: Kłodnica Fault region with associated faults in Main Saddle (SG) and Main Trough (NG) area.

Generally, the number of tremors with highest levels of energy, $10^{7} \mathrm{~J}, 10^{8} \mathrm{~J}$ and $10^{9} \mathrm{~J}$ has increased in recent years. The average number of tremors of $10^{7} \mathrm{~J}$ energy between 2001 to 2013 amounted to 17, whereas in the 2014 up to 64 tremors of the same as mentioned energy level occurred.

Over the whole 15-year period, recorded tremors included one or two tremors of $10^{8} \mathrm{~J}$ energy each year, with the exception of 2011, three such events, and in 2014 with up to 5 
tremors. One tremor of $10^{9} \mathrm{~J}$ energy occurred each year between 2008 and 2010, and in 2015, two [8].

The depth of exploitation is an important factor affecting the increase in seismic hazard especially after 2014 . The data in Table 1 show that as the mean depth of the areas where the rockbursts are recorded increases steadily, the average energy of tremors that caused rockbursts increases. This particularly refers to tremors with energies of $>10^{8} \mathrm{~J}$, for which the depth of the rockburst ranged from $980 \mathrm{~m}$ to $1,069 \mathrm{~m}$.

Table 1. Layout of the number of rockbursts against tremors that occurred between 2001 and 2015 according to energy level

\begin{tabular}{|c|c|c|c|c|c|}
\hline Tremor energy level E, J & $10^{5}$ & $10^{6}$ & $10^{7}$ & $10^{8}$ & $10^{9}$ \\
\hline No. of tremors, Nw, - & 14,824 & 2,801 & 333 & 23 & 4 \\
\hline No. of rock bursts Nt, - & 10 & 12 & 17 & 2 & 1 \\
\hline $\begin{array}{c}\text { The average energy of a tremor } \\
\text { that caused a rockburst Ea, J }\end{array}$ & $6.3 \cdot 10^{5}$ & $4.0 \cdot 10^{6}$ & $5.0 \cdot 10^{7}$ & $1.5 \cdot 10^{8}$ & $4.0 \cdot 10^{9}$ \\
\hline Average depth of rockbursts Ht, m & 858 & 830 & 813 & 980 & 1,069 \\
\hline
\end{tabular}

The above data show that the significant contribution of the number of rockbursts as compared to the number of tremors have events of energy level $>10^{7} \mathrm{~J}$.

However, high energy seismic tremors, $10^{8}$ and $10^{9} \mathrm{~J}$, are alarming, which occur more frequently than one in a year and have been recorded in the number of 2 to 5 tremors per year since 2006. The collected data indicate that 27 seismic events of $>10^{8} \mathrm{~J}$, recorded between 2001 and 2015, caused 3 rockbursts.

\section{Geological and mining factors determining the occurrence of rockbursts}

The recipes of Geological and Mining Law [1] stipulate that seams classified as the $1^{\text {st }}, 2^{\text {nd }}$, or $3^{\text {rd }}$ level of rockburst hazard are deposited "in rock mass and rocks prone to rockburst." Basically, in the conditions of tectonically not disturbed seams and rock masses, the level of rockburst hazard is determined by the stresses, the mechanical properties of the seam and the surrounding rocks and the seismicity generated by mining works.

The latter is the result of the damages of supported rocky rock layers with high strength parameters, and in particular the tremor-prone layers. They are thick, monolithic layers of sandstone and/or clay, of sufficiently high strength and thickness.

The risk of rockburst increases with the depth of the mining operation and the resulting increased stress in the rock and its gradient. $[11,12,13]$.

In view of the above, it can also be assumed that with general low stress, rockbursts will occur at relatively high levels of energy of rock mass tremors.

The stresses in the rock can significantly vary within the range of the impact for gobs and the reach of the impact imposed by edges, depending also on the vertical and horizontal distances from the excavation. Particularly unfavourable, due to the risk of rockburst, is summed up influence of the edges. Where the edge (seam, residue) is defined as the boundary line of the seam and gobs. 
Accumulated impact of edges and/or residue (large surfaces), including the effects of compacting faults, creates particularly unfavourable stress and deformation conditions in the rock mass, and thus increased rockburst hazard. The residue is defined as a shallow part of the seam surrounded by goafs, in a shape of an island, peninsula or headland, with a width of $10 \mathrm{~m}$ to $0.3 \mathrm{H}_{\mathrm{r}}$, which can concentrate stress (where: $\mathrm{H}_{\mathrm{r}}$ - depth of deposited residue).

In the seams, the residue most often occurs near faults that exceed the thickness of the exploited coal bed.

Particular cases of residue are support pillars (protective), usually cut by numerous excavations, that often lead to excessive seam development. The pillar of carbonaceous charcoal along the gobs is separated by a pavement parallel to the gobs located in the distance of $10 \mathrm{~m}$ to $50 \mathrm{~m}$. The support pillar, however, is a solid pillar with a width of 10 $50 \mathrm{~m}$ and located between parallel pavements.

The geological and mining factors mentioned in the mining regulations that affect the risk of rockburst include:

- faults,

- tremor-prone layers,

- edges,

- residue,

- support pillars,

and excessive seam development, particularly adversely affecting at greater depths ( $\geq 550 \mathrm{~m})$.

These factors represent a real threat of rockburst in active or developed mining excavations. Summarizes 42 rockbursts recorded in the years 2001-2015, grouped according to USCB structural units, the geological and geological factors characterizing the rock mass, and the location of recorded effects [2].

Data obtained in the location of the rockbursts indicate that these events occurred only in three regions of the USCB: Main Saddle (SG), Bytom Trough (NB), and Jejkowice and Chwałowice Troughs (NJ). The rockbursts that occurred in each of the area were conditioned by the interdependence of $\mathrm{Nt}=5$ of geological and mining factors.

Three of the events were registered in Main Saddle, energy reached $9 \cdot 10^{7}-4 \cdot 10^{9} \mathrm{~J}$ and were recorded at the exploitation level 910-1,069 m. One event was registered in Bytom Trough, energy reached $2 \cdot 10^{5} \mathrm{~J}$ at $930 \mathrm{~m}$. Jejkowice and Chwałowice Troughs were impacted by two rockbursts $(\mathrm{Nt}=5)$, energy levels reached $9 \cdot 10^{7} \mathrm{~J}$ and $1 \cdot 10^{8} \mathrm{~J}$ at $1,050 \mathrm{~m}$. (Table 2)

The most characteristic in terms of occurrence in the USCB rocky conditions are rockbursts caused by seismic tremors in operating conditions of the up to $\mathrm{N}_{\mathrm{t}}=5$ geological and mining factors. Although the tremors energy is $>2.00 \cdot 10^{5} \mathrm{~J}$, but their vast majority, as many as 5 rockbursts, are related to seismic shocks with energy of $E_{t}=9 \cdot 10^{7}-4 \cdot 10^{9} \mathrm{~J}$.

It should once again be stressed that the average shock energy of $7.47 \cdot 10^{8} \mathrm{~J}$ was related to rockbursts that occurred in the areas with the maximum number of geological and mining factors recorded. Such data translate into the "strength" of the impact of the identified 5 factors, expressed as the causes of rockbursts, and their effect on the extent of the effects of destruction and/or collapse of excavations [2].

Table 2 shows that 10 rockbursts, out of 42 analysed cases, occurred with the tremor energy of $10^{5} \mathrm{~J}$ and were determined by 3,4 and $5 \mathrm{Nt}$ respectively. The depth of underground mining operation (gallery and longwall) in the areas where the effects of these rockbursts occurred was between $550 \mathrm{~m}$ and 1,150 m. 
Table 2. Conditions of selected of tremors occurred in the USCB coal mines between 2001 and 2015

\begin{tabular}{|c|c|c|c|c|c|c|c|}
\hline Item & Mine/date & Seam & $\begin{array}{l}\text { Tremor } \\
\text { energy } E_{t}, J\end{array}$ & $\begin{array}{c}\text { Average } \\
\text { seam depth } \\
\mathrm{H}_{\mathrm{a}}, \mathrm{m}\end{array}$ & $\begin{array}{l}\text { Geological } \\
\text { factors } N_{\text {geol }}\end{array}$ & $\begin{array}{l}\text { Mining factors } \\
\mathrm{N}_{\text {gor }}\end{array}$ & $\begin{array}{l}\text { No. of } \mathrm{N}_{\mathrm{t}} \\
\text { factors; } \\
\text { geological } \\
\left(\mathrm{N}_{\text {geol }}\right) / \text { and } \\
\text { mining } \\
\left(\mathrm{N}_{\text {gor }}\right)\end{array}$ \\
\hline \multicolumn{2}{|c|}{$\begin{array}{l}\text { USCB Structural } \\
\text { unit }\end{array}$} & \multicolumn{6}{|c|}{ Main Saddle (SG) } \\
\hline 1 & $\begin{array}{l}\text { Wujek } \\
\text { Ruch } \\
\text { Śląsk, } 18 \\
\text { Apr 2015 }\end{array}$ & 409 & $4 \cdot 10^{9}$ & 1,069 & -faults & $\begin{array}{l}\text {-edges, } \\
\text {-residue, } \\
\text {-support } \\
\text { pillars, } \\
\text {-excessive } \\
\text { seam } \\
\text { development }\end{array}$ & $1 / 4$ \\
\hline 2 & $\begin{array}{l}\text { Pokój, } 27 \\
\text { July } 2006\end{array}$ & 502 & $9 \cdot 10^{7}$ & 970 & $\begin{array}{l}\text {-tremor- } \\
\text { prone layers, } \\
\text {-faults }\end{array}$ & $\begin{array}{l}\text {-edges, } \\
\text {-residue, } \\
\text {-excessive } \\
\text { seam } \\
\text { exploitation }\end{array}$ & $2 / 3$ \\
\hline 3 & $\begin{array}{c}\text { Halemba, } \\
22 \mathrm{Feb} \\
2006\end{array}$ & 506 & $2 \cdot 10^{8}$ & 910 & $\begin{array}{l}\text {-tremor- } \\
\text { prone layers, } \\
\text {-faults }\end{array}$ & $\begin{array}{l}\text {-residue, } \\
\text { support - } \\
\text { pillars, } \\
\text {-excessive } \\
\text { seam } \\
\text { exploitation }\end{array}$ & $2 / 3$ \\
\hline \multicolumn{2}{|c|}{$\begin{array}{l}\text { USCB Structural } \\
\text { unit }\end{array}$} & \multicolumn{6}{|c|}{$\begin{array}{l}\text { Bytom Trough } \\
\text { (NB) }\end{array}$} \\
\hline 4 & \begin{tabular}{|c|} 
ZG Bytom \\
II, 26 June \\
2001
\end{tabular} & 510 & $2 \cdot 10^{5}$ & 930 & $\begin{array}{l}\text {-tremor- } \\
\text { prone layers, } \\
\text {-faults, }\end{array}$ & $\begin{array}{l}\text {-edges, } \\
\text {-residue, } \\
\text {-support pillars }\end{array}$ & $2 / 3$ \\
\hline \multicolumn{2}{|c|}{$\begin{array}{c}\text { USCB Structural } \\
\text { unit }\end{array}$} & \multicolumn{6}{|c|}{$\begin{array}{l}\text { Jejkowice and Chwałowice Trough } \\
\text { (NJ) }\end{array}$} \\
\hline 5 & $\begin{array}{l}\text { Rydułtowy } \\
\text { Anna, } 13 \\
\text { May } 2006\end{array}$ & $703 / 1$ & $1 \cdot 10^{8}$ & 1,050 & $\begin{array}{l}\text {-tremor- } \\
\text { prone layers, } \\
\text {-faults }\end{array}$ & $\begin{array}{l}\text {-edges, } \\
\text {-residue, } \\
\text {-excessive } \\
\text { seam } \\
\text { exploitation }\end{array}$ & $2 / 3$ \\
\hline 6 & $\begin{array}{l}\text { Rydułtowy } \\
\text {-Anna, } 19 \\
\text { Dec } 2006\end{array}$ & $703 / 1$ & $9 \cdot 10^{7}$ & 1,050 & $\begin{array}{l}\text {-tremor- } \\
\text { prone layers, } \\
\text {-faults }\end{array}$ & $\begin{array}{l}\text {-edges, } \\
\text {-residue, } \\
\text {-excessive } \\
\text { seam } \\
\text { exploitation }\end{array}$ & $2 / 3$ \\
\hline
\end{tabular}

To summarize the above, it should be noted that in case of mining co-occurrence of five geological and mining factors, mentioned as the primary causes of rockbursts, it is absolutely necessary to expect high energy tremors of $>10^{8} \mathrm{~J}$ which, as a consequence, can cause mining disasters.

Interestingly, in no case of rockbursts, there have been 6 factors at once (Table 2 and 4).

By analysing the above, it should be mentioned that the concept of rockbursts with features of mining disaster is a phenomenon of high energy shock, which results in, among others, 
in the form of fatal accidents, collective and/or severe injuries among miners and complete destruction of significant lengths of mining excavations.

Table 4. The number of rockbursts, grouped according to energy level $\left(\mathrm{E}_{\mathrm{t}} \mathrm{J}\right)$ of seismic event and the number $\left(\mathrm{N}_{\mathrm{t}},-\right)$ of geological and mining factors

\begin{tabular}{|c|c|c|c|c|c|}
\hline $\mathrm{E}_{\mathrm{t}}$ & $10^{5}$ & $10^{6}$ & $10^{7}$ & $10^{8}$ & $10^{9}$ \\
\hline $\mathrm{N}_{\mathrm{t}}$ & - & - & - & - & - \\
\hline 6 factors & - & - & $\mathbf{2}$ & $\mathbf{2}$ & $\mathbf{1}$ \\
\hline 5 factors / 5 rockbursts & - & $\mathbf{7}$ & $\mathbf{1 3}$ & - & - \\
\hline 4 factors / 22 rockbursts & $\mathbf{1 0}$ & $\mathbf{5}$ & - & - & - \\
\hline 3 factors / 15 rockbursts &
\end{tabular}

This type of incident occurred in the case of three rockbursts recorded in the USCB mines in 2006 and 2015, which included, among others: fatal (2-4) and severe accidents (2-7), and extensive damage and destruction of excavations (with a reach of $>500 \mathrm{~m}$ ) [1] (Table 5).

Table 5. Geological and mining conditions of rockbursts in USCB coal mines with features of mining disasters

\begin{tabular}{|c|c|c|c|c|c|c|}
\hline $\begin{array}{l}\text { USCB Structural } \\
\text { unit }\end{array}$ & $\begin{array}{l}\text { Rockburst } \\
\text { data }\end{array}$ & $\begin{array}{l}\text { Depth, } \\
\mathrm{m}\end{array}$ & $\begin{array}{l}\text { Fatal } \\
\text { accidents } \\
\text { /other }\end{array}$ & $\begin{array}{l}\text { Length of } \\
\text { destroyed/da } \\
\text { maged } \\
\text { excavations, } \\
\text { m }\end{array}$ & $\begin{array}{l}\text { Tremor } \\
\text { energy } \\
\text { Et, J }\end{array}$ & $\begin{array}{l}\text { Geological and } \\
\text { mining factors of a } \\
\text { rockburst }\end{array}$ \\
\hline \multirow{2}{*}{$\begin{array}{l}\text { Main Saddle } \\
\text { (SG) }\end{array}$} & $\begin{array}{l}\text { Wujek Ruch } \\
\text { Śląsk, } 18 \\
\text { Apr } 2015\end{array}$ & 1,069 & $2 /-$ & $1200 /-$ & $4 \cdot 10^{9}$ & $\begin{array}{l}\text {-faults, } \\
\text {-edges, } \\
\text {-residue, } \\
\text {-support pillars, } \\
\text {-excessive seam } \\
\text { exploitation }\end{array}$ \\
\hline & $\begin{array}{l}\text { Halemba, } 22 \\
\text { Feb } 2006\end{array}$ & 910 & $-/ 2$ & $\begin{array}{l}\text { Not } \\
\text { determined } \\
>500\end{array}$ & $2 \cdot 10^{8}$ & $\begin{array}{l}\text {-tremor-prone - } \\
\text { layers, } \\
\text {-faults } \\
\text {-residue, } \\
\text {-support pillars, } \\
\text {-excessive seam } \\
\text { exploitation }\end{array}$ \\
\hline $\begin{array}{l}\text { Jejkowice and } \\
\text { Chwałowice } \\
\text { Trough (NJ) }\end{array}$ & $\begin{array}{l}\text { Rydułtowy } \\
\text { Anna, } 13 \\
\text { May } 2006\end{array}$ & 1,050 & $4 / 7$ & $-/ 300$ & $1 \cdot 10^{8}$ & $\begin{array}{l}\text {-tremor-prone - } \\
\text { layers, } \\
\text {-faults, } \\
\text {-edges, } \\
\text {-residue, } \\
\text {-excessive seam } \\
\text { exploitation }\end{array}$ \\
\hline
\end{tabular}

\section{Conclusion}

Based on seismic statistics in hard coal mines in Poland, it has been proven that such phenomena have started to occur in Polish hard coal mines only recently. The first of them was recorded in 2006, next in 2010, 2012 and in 2015.

Geological and mining conditions of rockbursts in USCB coal mines with tremor energy of $>10^{7} \mathrm{~J}$ causing mining disaster are shown in Table 5 . 
A detailed analysis of rockbursts with tremor energy of $>10^{7} \mathrm{~J}$ indicates the coincidence of 4 and $5 \mathrm{~N}_{\mathrm{t}}$ factors, including mainly one geological factor $\left(\mathrm{N}_{\text {geol }}\right)$, fault, and two mining factors $\left(\mathrm{N}_{\mathrm{gor}}\right)$, i.e.: residue and excessive development or exploitation of a seam.

This indicates the specificity of the current mining operation, most often below $900 \mathrm{~m}$, under the influence of fault zones located in the areas of former exploitation, including in particular the excessive exploitation of a seam (Table 5).

\section{References}

1. Geological and Mining Law. J.L. 2011 No. 163 item 981, Act dated 9 June 2011.

2. R. Patyńska i in., Rockburst hazard. [in] Raport roczny o stanie zagrożeń naturalnych i technicznych w górnictwie węgla kamiennego. Central Mining Institute, Katowice (2002-2016)

3. K. Stec i in., Seismic hazards. [in]: Raport roczny o stanie zagrożeń naturalnych i technicznych w górnictwie węgla kamiennego. Central Mining Institute, Katowice (2002-2016)

4. I. Skrzypczak, A. Sobkowiak, W. Kokoszka, J. Kogut. The impact of underground mining on the threat of building structures. 17th International Multidisciplinary Scientific Geoconference - SGEM 2017, Proceedings vol 17, issue 11, Science Technologies in Geology, Exploration and Mining, pp. 623-630, ISSN 1214-2704, Albena, Bulgaria, 2017

5. R. Patyńska, Rock bursts and tectonics of the Upper Silesian Coal Basin. XXVII Zimowa Szkoła Mechaniki Górotworu, Wyd. Katedry Geomechaniki Budownictwa i Geotechniki Tom II, Kraków. p. 741-753 (2004)

6. R. Patyńska, Mining and geological conditions of exploitation of seams with rock burst hazard between 1987 and 2007. Wydawnictwo IGSMiE PAN, Gospodarka Surowcami Mineralnymi, Kwartalnik, Vol. 24- Book 2/3, Kraków, p. 227-243 (2008)

7. Z. Burtan, The importance of associated natural hazards in the Upper Silesian Coal Basin. Przegląd Górniczy, Vol. 11, p. 21-29 (2016)

8. R. Patyńska, K. Stec, Regional Rockburst Indicator for structural units of Upper Silesian Coal Basin. Studia Geotechnica et Mechanica, Vol. 39 (2017). No. 2, Wrocław 2017, p. 1-14 (2017)

9. K. Stec, Characteristics of Seismic Activity of the Upper Silesian Coal Basin in Poland. Geophysical Journal International, Blackwell Publishing Ltd, V 168. p. 213219 (2007)

10. K. Stec, Seismic activity of Upper Silesian Coal Basin and its relationship with the geological properties of rock mass and parameters of mining operation. [in]: Stateczność Górotworu i obudowy przy łącznym obciążeniu statycznym i dynamicznym" (ed. A. Kidybiński), Wyd. Central Mining Institute, Katowice, p. 8-48 (2009)

11. J. Dubiński, W. Konopko, Rockbursts - assessment - forecast - fighting. Wydawnictwo GIG, Katowice (2000)

12. W. Konopko, R. Patyńska, Conditions of occurrence of rock bursts in coal mines. Przegląd Górniczy, Vol. 1, p. 12-17 (2008)

13. W. Konopko et al., Work safety in coal mines. Wydawnictwo GIG, Vol 2, Katowice, p.169-230 (2013) [12] 